Research Article

\title{
Survival of White-Tailed Deer Neonates in Louisiana
}

\author{
REBECCA M. SHUMAN (DD, ${ }^{\mathbf{1 , 2}}$ Daniel B. Warnell School of Forestry and Natural Resources, University of Georgia, Athens, GA 30602, USA \\ MICHAEL J. CHERRY, Department of Fish and Wildlife Conservation, Virginia Polytechnic Institute and State University, Blacksburg, VA 24061, USA \\ TAYLOR N. SIMONEAUX, Daniel B. Warnell School of Forestry and Natural Resources, University of Georgia, Athens, GA 30602, USA \\ ELIZABETH A. DUTOIT, Daniel B. Warnell School of Forestry and Natural Resources, University of Georgia, Athens, GA 30602, USA \\ JOHN C. KILGO, USDA Forest Service, Southern Research Station, P.O Box 700, New Ellenton, SC 29809, USA \\ MICHAEL J. CHAMBERLAIN, Daniel B. Warnell School of Forestry and Natural Resources, University of Georgia, Athens, GA 30602, USA \\ KARL V. MILLER, Daniel B. Warnell School of Forestry and Natural Resources, University of Georgia, Athens, GA 30602, USA
}

\begin{abstract}
Changing predator communities have potential to complicate management focused on ensuring sustainable white-tailed deer (Odocoileus virginianus) populations. Recent research reported that predation on neonates by coyotes (Canis latrans) and bobcats (Lynx rufus) can limit recruitment. However, no research has been conducted in areas of the southeastern United States with 3 sympatric neonate predators such as coyote, American black bear (Ursus americanus), and bobcat. Our objectives were to estimate neonate survival rates, identify causes of neonate mortality, and determine which biological and landscape characteristics were related to neonate survival. During 2013-2015, we captured 70 neonates with the aid of vaginal implant transmitters on Tensas River National Wildlife Refuge in northeastern Louisiana, USA. We monitored neonates every 8 hours until 6 weeks of age and daily until 12 weeks of age, and assigned cause of death from field and DNA evidence. Survival of neonates to 12 weeks was $0.271(95 \% \mathrm{CI}=0.185-0.398)$. Of 51 mortalities, 45 (88\%) were attributed to predation, $4(8 \%)$ to starvation, $1(2 \%)$ to other causes, and $1(2 \%)$ to unknown causes. We used an information-theoretic approach to compare Cox proportional hazards models containing various combinations of biological and habitat covariates. Our best-supported model contained sex, mass at birth, distance to cropland, young reforestation (planted 2000-2009), and old reforestation (planted 1980-1989). Based on hazard ratios, survival was $81 \%$ higher for males than females, and survival increased $81 \%$ with every $1-\mathrm{kg}$ increase in birth mass. Survival increased $8 \%$ for every $100-\mathrm{m}$ increase in distance from cropland or young reforestation, and decreased $11 \%$ with every $100-\mathrm{m}$ increase in distance from old reforestation, which may be a result of spatial variation in predator distribution. Our results emphasize the importance of site-specific monitoring of neonate recruitment rates in areas with burgeoning predator communities. We conclude, however, that although predation pressure was high, survival rates were similar to those observed in 2-predator systems in the region, suggesting the possibility that an upper limit to predation rates may exist for white-tailed deer neonates. (C) 2017 The Wildlife Society.
\end{abstract}

KEY WORDS black bear, bobcat, coyote, fawn, habitat, Odocoileus virginianus, predation, recruitment.

Understanding recruitment rate is important for management of sustainable white-tailed deer (Odocoileus virginianus) herds and development of appropriate harvest strategies (Porath 1980). Because the life stage most susceptible to mortality is neonates, reliable estimates of their survival are important for population modeling and herd management (Roseberry and Woolf 1991, Bowden et al. 2000). In a review

Received: 23 August 2016; Accepted: 13 February 2017

${ }^{1}$ E-mail: becky.shuman@myfwc.com

${ }^{2}$ Present Address: Division of Hunting and Game Management, Florida Fish and Wildife Conservation Commission, Gainesville, FL 32601, USA. of predation effects on neonatal ungulate mortality, Linnell et al. (1995) reported mortality rates of neonates in northern temperate regions were variable $(0-100 \%)$, and predation accounted for $0-100 \%$ of those mortalities, suggesting that predation levels are site-specific. This recognized spatial variation in predation rates mandates site-specific research to determine cause-specific mortality of neonates and potential impacts of predation on deer recruitment. Moreover, declines in deer recruitment rates in some areas of the southeastern United States, specifically due to predation on neonates, have become a concern in recent years (Howze et al. 2009, Kilgo et al. 2010). Neonate survival studies in this region have documented low survival rates (14-33\%), with most mortalities attributed to predation (63-90\%; Epstein 
et al. 1985, Kilgo et al. 2012, Jackson and Ditchkoff 2013, Chitwood et al. 2015b, Nelson et al. 2015). In areas with populations below carrying capacity, declining populations may necessitate reduction of antlerless harvest (Robinson et al. 2014), and in areas of low recruitment, cessation of antlerless harvest and predator control may be necessary to offset population declines (Chitwood et al. 2015a).

Most studies examining neonate survival rates in the southeastern United States have implicated coyotes (Canis latrans) as the leading source of neonate mortality (Kilgo et al. 2014, Chitwood et al. 2015b, Nelson et al. 2015). These studies, however, were conducted in 2-predator systems, where coyotes and bobcats (Lynx rufus) were the primary predators of neonates. No research has occurred in the southeastern United States in areas with 3 primary predators, specifically coyotes, bobcats, and American black bears (Ursus americanus). The combined effects of multiple predators on prey survival often cannot be predicted from their individual effects (McCoy et al. 2012), and predation on neonates by this additional predator may be an additive or compensatory source of mortality. Neonates are a food source of black bears (Ozoga and Verme 1982), and studies in Pennsylvania, Minnesota, and New York, USA, have reported black bears to be responsible for $25-60 \%$ of mortalities attributable to predation (Mathews and Porter 1988, Kunkel and Mech 1994, Vreeland et al. 2004, Carstensen et al. 2009). Black bears can be an important source of mortality for neonates in northern areas, but whether this same trend is present in areas of the southeastern United States where black bears occur is unclear.

Biological factors, such as sex, birth mass, and date of birth, can influence neonate survival (Saalfield and Ditchkoff 2007, Bishop et al. 2009). Male neonates may be more susceptible to predation (Bishop et al. 2009) based on differences in activity patterns. Jackson et al. (1972) reported that male neonates were more active than females, and male neonates have a propensity to be more independent of the dam (Taber and Dasmann 1954). Additionally, birth mass can be a critical factor in neonatal ungulate survival (Verme 1969, Thorne et al. 1976, Cook et al. 2004, Lomas and Bender 2007), and heavier offspring often have increased body growth rates compared to lighter offspring (Verme 1989, Steiger 2013). The influence of date of birth on survival of neonates is variable. Many studies conducted where predation was a significant source of mortality on neonates reported no effect of birth date on survival (Vreeland et al. 2004, Saalfeld and Ditchkoff 2007, Chitwood et al. 2015b), whereas other research has documented that the probability of neonate survival was greatest for those born early in the season and declined with later birth dates (Lomas and Bender 2007, Bishop et al. 2009, Kilgo et al. 2012). This decline was attributed to stress, malnutrition, and disease on smaller, later-born young during winter, or to increases in nutritional demand or hunting skills of predators throughout the birthing season. Conversely, Whittaker and Lindzey (1999) documented higher survival rates for white-tailed and mule deer (O. hemionus) neonates born later in the season, potentially attributable to the swamping effect as more neonates are on the landscape as the birthing season progresses. In moderate to high density deer populations, abundance of neonates during a short time period likely overwhelms predator populations, and individual neonates should be at a reduced risk of predation (Clark and Robertson 1979, O’Donoghue and Boutin 1995, Fritts and Pearsons 2008).

Habitat characteristics affect distribution, density, and hunting efficacy of predators (Gese et al. 1996, Dijak and Thompson 2000) and can influence neonate survival. Although several studies have quantified microhabitat characteristics of neonate bed sites (Garner et al. 1979, Huegel et al. 1985, Nelson 2013) and their link to neonate survival (Chitwood et al. 2015b), little is known regarding the influence of landscape characteristics on neonate survival. Vreeland et al. (2004) reported that neonates in Pennsylvania were $>2$ times more likely to survive 9 weeks post-capture in agricultural areas than in forested areas but did not observe any effects of landscape variables (e.g., edge density, habitat diversity) on survival. Conversely, studies in Illinois (Rohm et al. 2007) and South Dakota, USA, (Grovenburg et al. 2012) reported that landscape characteristics (e.g., edge density, patch size, and density) influenced neonate survival.

Deer herds exist throughout spatially variable landscapes, with dynamic predator communities and changing habitat conditions. Predation is a complex phenomenon and, coupled with the complexity under which deer herds exist, mandates site-specific research aimed at developing science-based management programs designed to ensure sustainability of deer herds. Our objectives were to estimate neonate survival rates, identify causes of neonate mortality, and determine which biological and landscape characteristics were related to neonate survival.

\section{STUDY AREA}

We conducted research on a 5,700-ha study area (hereafter Tensas; Fig. 1) located in northeastern Louisiana in the upper Tensas River Basin. Tensas included portions of Tensas River National Wildlife Refuge (TRNWR) and adjacent private lands and was delineated by physical and property boundaries. The 30,750-ha refuge was established in 1980 and was once extensively logged hardwoods and agricultural lands. Since acquisition by the United States Fish and Wildlife Service, forests on the refuge have been allowed to grow into mature bottomland hardwood and swamps, and former agricultural fields have been replanted in native hardwoods. The TRNWR was bordered almost entirely by agriculture on all sides, making it an island of habitat for many species including deer and the Louisiana black bear (U. a. luteolus).

Topography was flat to slightly undulating with $0-8 \%$ slopes and elevations ranging from $17 \mathrm{~m}$ to $23 \mathrm{~m}$ above mean sea level (U.S. Geological Survey 1995). Soils were alluvial in nature, poorly drained but highly fertile, and were comprised mostly of the Tensas, Sharkey, or Alligator series (U.S. Department of Agriculture 1968). The climate of Tensas was humid subtropical. Mean annual temperature was $19^{\circ} \mathrm{C}$, 


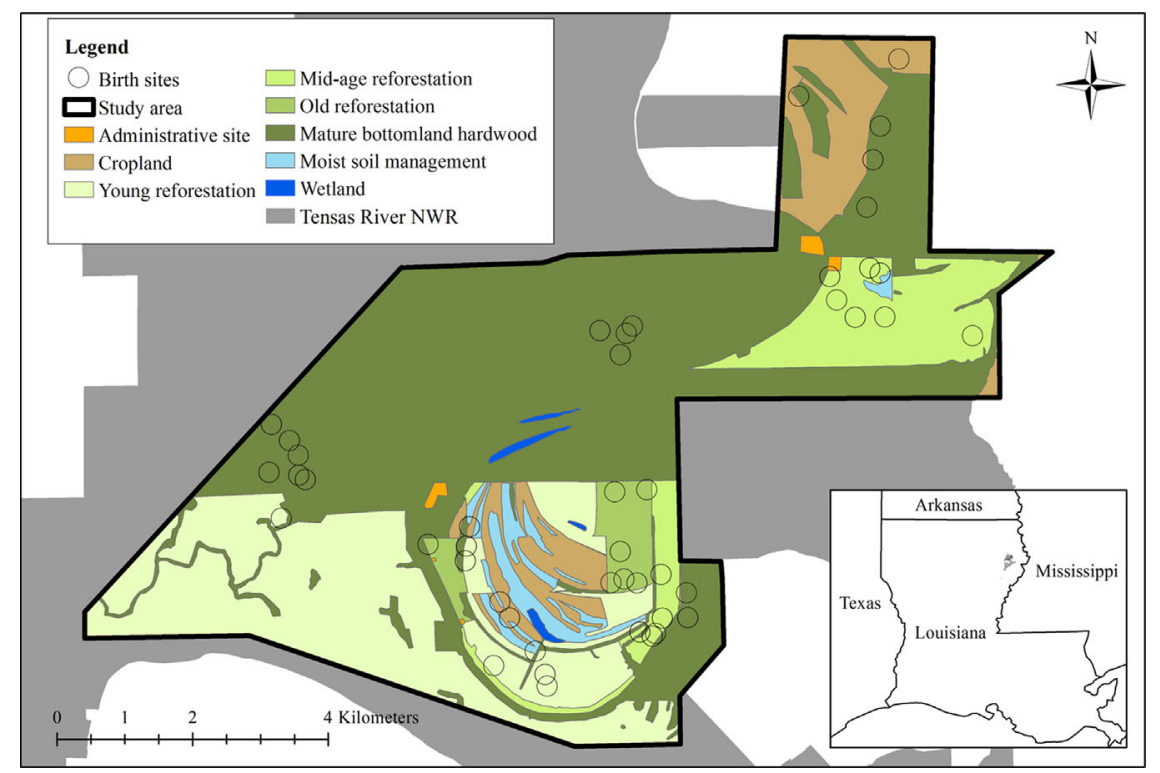

Figure 1. Tensas River National Wildlife Refuge, Louisiana, USA, including study area boundaries, birth site locations of radio-collared white-tailed deer neonates, and vegetation cover types.

with mean high and low temperatures of $25^{\circ} \mathrm{C}$ and $12^{\circ} \mathrm{C}$, respectively, and annual precipitation averaged $130 \mathrm{~cm}$ (National Oceanic and Atmospheric Administration 2015).

Vegetation cover types on Tensas consisted primarily of mature bottomland hardwoods (51.4\%), early to midsuccessional hardwood plantings (37.3\%), and agricultural crops (8.5\%). Overstory vegetation consisted of water oak (Quercus nigra), willow oak (Q. phellos), hickory (Carya spp.), sweetgum (Liquidambar styraciflua), elm (Ulmus spp.), ash (Fraxinus spp.), and sugarberry (Celtis laevigata), with interspersed baldcypress (Taxodium distichum) and tupelo (Nyssa aquatica) swamps. Understory consisted of dwarf palmetto (Sabal minor), poison ivy (Toxicodendron radicans), trumpet creeper (Campsis radicans), and greenbrier (Smilax spp.). Several mast-producing species such as blackberry (Rubus spp.) and pokeweed (Phytolacca americana) were abundant along roads and edges and where forest management practices have maintained a more open canopy. Early to mid-successional hardwood plantings established for carbon credits were distributed throughout TRNWR. These plantings were initiated between 1985 and 2009. Agricultural crops grown on Tensas included corn (Zea mays), cotton (Gossypium birsutum), soybean (Glycine max), and rice (Oryza sp.).

Deer densities on TRNWR were approximately 17-22 deer $/ \mathrm{km}^{2}$ (R. S. Durham, Louisiana Department of Wildlife and Fisheries, personal communication). Annual harvest on TRNWR during the study averaged $903 \pm 55$ (SE) deer/ year, a decline from the average of $1,197 \pm 49$ deer/year in the 1990s (J. Dickson, U.S. Fish and Wildlife Service, personal communication). Annual survival of yearling and adult females during the study averaged 0.82 and 0.86 , respectively, and population growth was stable $(\lambda=1.0$; Shuman 2016). Since the creation of TRNWR, black bear densities have increased from approximately $0.11 / \mathrm{km}^{2}$ in the 1980s (Nowak 1986) to $0.36 / \mathrm{km}^{2}$ in the late 1990 s (Boerson et al. 2003) to $0.66 / \mathrm{km}^{2}$ in the late 2000s (Hooker 2010). Bobcat and coyote densities on Tensas are unknown. Although bobcat and bear hunting on the refuge are prohibited, coyotes are not considered a game species and may be harvested incidentally during any hunting season with the weapons legal for that season.

\section{METHODS}

\section{Capture and Monitoring}

During January-April 2013-2015, we captured adult ( $\geq 1.5$ years) females using a combination of drop nets $(18.3 \mathrm{~m}$ $\times 18.3 \mathrm{~m}$ or $15.2 \mathrm{~m} \times 15.2 \mathrm{~m})$, rocket nets $(12.2 \mathrm{~m}$ or $18.3 \mathrm{~m})$, and darting with a tranquilizer gun (Dan-Inject, Børkop, Denmark) from a tree stand over bait. We anesthetized deer caught under nets with an intramuscular injection of ketamine hydrochloride $(3.5 \mathrm{mg} / \mathrm{kg}$; Congaree Veterinary Pharmacy, Cayce, SC, USA) and xylazine hydrochloride $(2.5 \mathrm{mg} / \mathrm{kg}$; Congaree Veterinary Pharmacy). When darting, we used Telazol (250 mg; Fort Dodge Animal Health, Fort Dodge, IA, USA) and xylazine hydrochloride $(225 \mathrm{mg}$; Congaree Veterinary Pharmacy) in 1-ml Pneu-Dart transmitter darts (PneuDart, Williamsport, PA, USA). We radio-collared (Model 2510B, Advanced Telemetry Systems, Isanti, MN, USA) and implanted each female with a temperature-activated vaginal implant transmitter (VIT; 2013 and 2015; Model M3930, Advanced Telemetry Systems) or a temperature- and lightactivated VIT (2014; M3930L, Advanced Telemetry Systems; Cherry et al. 2013). Implantation procedures generally followed those described by Carstensen et al. (2003), except that we did not trim the protruding antenna (Kilgo et al. 2012). Following instrumentation, we reversed the xylazine hydrochloride with tolazoline hydrochloride $(150 \mathrm{mg}$ intravenous and $150 \mathrm{mg}$ intramuscular; Congaree Veterinary Pharmacy) and monitored the deer until ambulatory. Capture and 
handling protocol was approved by the University of Georgia Institutional Animal Care and Use Committee (permit A2012 06-006-Y3-A2).

We monitored female very high-frequency collar and VIT signals weekly from capture until 1 June, then daily until the first birth, and at 8-hour intervals (beginning at 0600, 1400, and 2200) until the last birth. The VITs were equipped with either a thermistor that detected and signaled a change in temperature related to expulsion of the transmitter during parturition, or a thermistor and photo sensor, which detected and signaled a change in light associated with expulsion of the transmitter. In VITs with a thermistor and photo sensor, the VIT signaled when it detected a change in light, a change in temperature, or both. In addition, all VITs were equipped with a timer that specified number of 30-minute intervals that elapsed since the temperature or light change. If we detected an expelled VIT within 2 hours of parturition, we waited until $\geq 2$ hours had elapsed before initiating a search to allow for grooming and initial bonding between the female and neonate. Otherwise, we began a search with thermal imaging cameras immediately after detecting an expelled VIT. We proceeded first to the female, if not at the VIT, and then to the VIT, and recorded the location of each. If we did not locate a neonate at the VIT, we searched an area of approximately $150 \mathrm{~m}$ between and around the female and VIT locations. If we did not find a neonate on the initial search, we returned at 8-24-hour intervals over the following 1-3 days for additional searches. All searches lasted $\leq 2$ hours to limit human disturbance.

When we located neonates, we immediately blindfolded them and only handled them with non-scented latex gloves. We placed neonates in a cotton bag and weighed them to the nearest $0.01 \mathrm{~kg}$. We determined sex and attached an expandable breakaway radio-collar (Model M4210, Advanced Telemetry Systems) equipped with a motionsensitive mortality switch on a 4-hour delay. Neonates were then released at the capture location. We classified litter size as twin set if 2 neonates were found at or near the birth site within 24 hours of parturition. To minimize the possibility of misidentifying litter size, we assigned litter size as singleton only when both the female and neonate were found at the birth site within 6 hours of parturition, and we classified all other single neonates as unknown litter size.

To estimate survival, we monitored neonates every 8 hours (beginning at 0600,1400, and 2200) until 6 weeks of age and once daily until 12 weeks of age. Because the greatest probability of mortality occurs during the first few weeks of life (Cook et al. 1971, Kilgo et al. 2012), we monitored neonates more intensively at younger ages. Frequent monitoring allowed for better detection of mortalities, estimation of time of death, and preservation of evidence used to determine cause of mortality. We were able to reach most carcasses in $\leq 3$ hours of detection of mortality signal (45 of 51) and all within 8.5 hours.

We estimated neonate locations every 32 hours (every fourth mortality check) from birth until 6 weeks of age via triangulation. We collected $\geq 3$ bearings within 20 minutes (Millspaugh and Marzluff 2001) from distances $\geq 50 \mathrm{~m}$ from the neonate's location and used the maximum likelihood estimator in Location of A Signal software (version 4.0.3.8; Ecological Software Solutions LLC, Sacramento, CA, USA) to estimate locations and accepted only locations with an error ellipse of $\leq 2 \mathrm{ha}$.

\section{Fate Determination}

We assigned cause of mortality based on field evidence at or near the collar or remains. When evidence suggested predation as cause of death, we examined carcasses for subcutaneous hemorrhaging beneath bite marks or aspirated blood in the trachea to discern whether predation was the cause of death or the carcass had only been scavenged after dying from other causes. We identified the predator responsible based on cache characteristics, size of feeding area, consumption patterns, and tracks or scat at the mortality site. Bobcats tend to cache remains under sticks, leaf litter, or debris without digging into the mineral soil, but if coyotes cache their prey, they typically bury it in the mineral soil (O'Gara 1978, Labisky and Boulay 1998). Black bears rarely scatter remains and tend to have one relatively large feeding site (1-5 $\mathrm{m}$ in diameter) where vegetation is usually matted down (Schlegel 1976, Wade and Bowns 1984), whereas coyotes often scatter remains over a larger area (Cook et al. 1971, O'Gara 1978). Coyotes and black bears are more likely to consume the entire carcass than bobcats (Garner et al. 1976, Epstein et al. 1983, Wade and Bowns 1984). Bobcats often initiate feeding on the shoulders, whereas coyotes feed first on the viscera and hindquarters, and black bears favor the inguinal and loin areas (White 1973, O'Gara 1978). Additionally, black bears often consume ears, eyes, and tongue and invert the hide when most of the carcass is consumed (Ballard et al. 1979, Wade and Bowns 1984).

When no evidence of predation was present and the carcass was emaciated, we listed the cause of death as starvation. When no evidence of predation or emaciation was present, we listed cause of death as other causes. We submitted carcasses that did not exhibit signs of predation to the Southeastern Cooperative Wildlife Disease Study (Athens, GA, USA) or Louisiana Department of Wildlife and Fisheries (Baton Rouge, LA) for full necropsy to confirm cause of death. Because of the potential for marking-induced abandonment, some researchers remove starved neonates from their samples. However, other research has suggested that the risk of marking-induced abandonment is minimal (Ozoga and Clute 1988, Carstensen Powell et al. 2005). Natural abandonment is commonly reported in deer and is attributable to various causes (Verme 1969, Langenau and Lerg 1976), and omitting starved neonates can underestimate natural mortality. Therefore, we retained starved neonates in our analyses.

To confirm our field assignment of predator species, we collected residual predator saliva for DNA identification of species. We wiped cotton swabs around bite wounds, on the head and neck of the neonate, and on the radio-collar. We swabbed $\geq 3$ different locations on the remains of each neonate to maximize detection of multiple predator species if present. Wildlife Genetics International (WGI; Nelson, Canada) conducted genetic analyses of saliva by extracting DNA from material clipped from the swab using QIAGEN 
DNeasy Blood and Tissue kits (Valencia, CA, USA). The species test was a partial sequence analysis of the mitochondrial 16S rRNA gene (Johnson and O'Brien 1997). Wildlife Genetics International first used Carnivora-specific primers to amplify the $16 \mathrm{~S}$ sequence, and then compared the sequence profiles from samples with reference data from over 125 mammalian species.

When we recovered predator or scavenger DNA from remains, even in the absence of definitive field evidence, we assigned cause of mortality to that predator species. If DNA analyses could not identify predator species or produced mixed samples, we relied on field evidence to assign predator species. If field evidence suggested predation but species could not be determined by field or DNA evidence, we listed cause of death as unknown predator. We recognize that predators could scavenge neonates that died of other causes before we recovered them, but our intensive monitoring schedule was designed to minimize this potential.

\section{Landscape Variables}

Because of variable life spans across our sample of neonates, there was considerable variability in number of relocations ( $n=1-32)$, thus precluding our ability to delineate individual home ranges for use in landscape analyses. Therefore, to characterize landscape variables associated with neonate survival, we calculated distance in 100-m increments from each neonate location to each habitat or edge as a metric for habitat use. We classified land cover into 7 different types based on differences in vegetative species composition and tree size: mature bottomland hardwoods, young reforestation (planted 2000-2009), mid-age reforestation (planted 19901999), old reforestation (planted 1980-1989), cropland, moist soil management areas, and administrative sites (i.e., refuge offices). We used a combination of interpretation of National Agriculture Imagery Program (NAIP) aerial imagery taken in 2013 and TRNWR forestry records (N.J. Renick, U.S. Fish and Wildlife Service, unpublished data) to classify land cover types and created shapefiles of each land cover type in ArcGIS 10.2 (Environmental Systems Research Institute, Redlands, CA, USA). To facilitate ease of distance calculations, we used the land cover layers to create distance raster layers where each $10-\mathrm{m} \times 10-\mathrm{m}$ cell contained distance to the nearest cell of each land cover type. In R (version 3.2, R Core Team, Vienna, Austria), we used the raster package to create a raster stack of all raster layers. We then overlaid neonate locations onto the raster stack and calculated mean distance to each land cover type and nearest edge between 2 types for each neonate.

\section{Statistical Analysis}

We conducted known-fate modeling using the survival package in $\mathrm{R}$ to determine survival rates and examine factors potentially affecting survival. We estimated survival rate to 12 weeks using the Kaplan-Meier method and neonate age in days rather than a staggered entry approach (Bishop et al. 2008). We estimated a 12 -week survival rate rather than $16-$ or 26-week survival because most neonates reached 12 weeks of age by mid-October to early November, which coincided with opening of deer hunting season, when we considered neonates recruited into the hunted population.
We analyzed differences in biological factors among years using analysis of variance. We used Cox-proportional hazards survival models to investigate effects of biological factors (capture year, sex, birth mass, and ordinal date of birth) and landscape variables on neonate survival. We constructed 27 a priori models containing various combinations of biological factors and landscape variables. For model selection, we used Akaike's Information Criterion adjusted for sample size $\left(\mathrm{AIC}_{c}\right)$. We used Akaike weights $\left(w_{i}\right)$ to evaluate strength of evidence among competing models and considered our most plausible models to be those $\leq 2.0 \mathrm{AIC}_{c}$ units from the top model (Burnham and Anderson 2002). We checked model assumption of proportionality by examining Schoenfeld residuals.

\section{RESULTS}

We implanted 30 adult females in 2013, 32 in 2014, and 40 in 2015 with VITs. We captured 11 females during 2 years, resulting in 102 VIT deployments among 91 individual females. We successfully captured $\geq 1$ live neonate from 46 of the 102 VITs (45\%), yielding 70 neonates (28 in 2013, 17 in 2014, and 25 in 2015). From these births, we documented 24 twin sets, 10 singletons, and 12 with unknown litter size. Reasons for failure to collar neonates from monitored VITs included transmitter failure prior to parturition $(n=29)$, failure to locate neonates after apparently normal parturition $(n=12)$, death of female prior to parturition $(n=7)$, expulsion of VIT prior to parturition $(n=3)$, stillbirth of neonates $(n=3)$, loss of contact with female prior to parturition $(n=1)$, and female was not pregnant when implanted $(n=1)$.

Mean date of birth was 15 July and differed across years $\left(F_{2,67}=4.22, P=0.02\right)$. In 2015 , mean date of birth was earlier (10 Jul) than in 2013 (19 Jul) and 2014 (15 Jul). The earliest dates of birth were 5 July in 2013, 5 July in 2014, and 25 June in 2015; latest dates of birth were 8 August in 2013, 30 July in 2014, and 15 August in 2015. Sex ratio among neonates was biased toward males ( 42 of $70,60 \%$ ) in all years: 15 of 28 (54\%) in 2013, 9 of 17 (53\%) in 2014, and 18 of 25 $(72 \%)$ in 2015 . Neonate mass averaged $3.00 \pm 0.48$ (SD) kg (Table 1). Mass did not vary among years $\left(F_{2,65}=0.47\right.$, $P=0.63)$ but did by sex $\left(F_{1,66}=11.33, P<0.01\right)$; males $(3.14 \pm 0.48 \mathrm{~kg})$ weighed more than females $(2.76 \pm 0.41 \mathrm{~kg})$.

Survival to 12 weeks was 0.271 (95\% CI $=0.185-0.398)$. Survival rates were similar across years, and $95 \%$ confidence intervals overlapped among all years (Table 2). Neonate survival decreased rapidly during the first 7 days of life, with $50 \%(95 \% \mathrm{CI}=37.2-60.4 \%)$ of neonates dying during that period, whereas no neonates died after 44 days (Fig. 2).

We identified 2 plausible models (i.e., within $2 \mathrm{AIC}_{c}$ units) that predicted risk to neonate survival (Table 3). The bestsupported model included sex, mass, distance to cropland, distance to young reforestation, and distance to old reforestation (Table 3). Based on hazard ratios, survival was $81 \%$ greater for males than females (Table 4). Survival increased with mass, distance to cropland, and distance to young reforestation, and decreased with distance to old reforestation (Table 4). For every 1-kg increase in birth mass, 
Table 1. Mean, standard deviation, minimum, and maximum values for continuous covariates used in Cox proportional hazard models predicting risk to white-tailed deer neonate survival on Tensas River National Wildlife Refuge, Louisiana, USA, 2013-2015.

\begin{tabular}{lrrrr}
\hline Covariate $^{\mathbf{a}}$ & \multicolumn{1}{c}{$\overline{\boldsymbol{x}}$} & \multicolumn{1}{c}{ SD } & Min. & Max. \\
\hline Mass & 3.00 & 0.48 & 1.67 & 4.42 \\
Administrative sites & 18.03 & 10.12 & 2.49 & 33.47 \\
Cropland & 9.57 & 9.99 & 0.10 & 29.88 \\
Moist soil & 11.06 & 10.87 & 0.00 & 30.83 \\
Wetland & 23.91 & 17.73 & 2.20 & 67.95 \\
Hardwood & 1.14 & 1.58 & 0.00 & 6.69 \\
Young reforestation & 17.17 & 22.83 & 0.00 & 74.34 \\
Mid-age reforestation & 9.03 & 9.93 & 0.00 & 29.96 \\
Old reforestation & 20.09 & 19.14 & 0.00 & 69.44 \\
Edge & 2.76 & 3.18 & 0.10 & 11.69 \\
\hline
\end{tabular}

a mass, mass at birth (kg); administrative sites, distance to administrative sites $(100 \mathrm{~m})$; cropland, distance to cropland $(100 \mathrm{~m})$; moist soil, distance to moist soil management area $(100 \mathrm{~m})$; wetland, distance to wetland $(100 \mathrm{~m})$; hardwood, distance to mature bottomland hardwood $(100 \mathrm{~m})$; young reforestation, distance to young reforestation (planted 2000-2009; $100 \mathrm{~m}$ ); mid-age reforestation, distance to mid-age reforestation (planted 1990-1999; $100 \mathrm{~m}$ ); old reforestation, distance to old reforestation (planted 1980-1989; $100 \mathrm{~m})$; edge, distance to edge (100 m).

survival increased by $81 \%$. For every $100-\mathrm{m}$ increase in distance from young reforestation or cropland, survival increased by $8 \%$, and survival decreased $11 \%$ with every $100-\mathrm{m}$ increase in distance from old reforestation.

Of 70 neonates, we recorded 51 mortalities: 18 in 2013, 13 in 2014, and 20 in 2015. Predation was the leading source of mortality $(n=45 ; 88.2 \%)$, followed by starvation $(n=4$; $7.8 \%)$, other causes $(n=1 ; 2.0 \%)$, and unknown cause of death $(n=1 ; 2.0 \%$; Table 5). Among neonates for which field evidence indicated predation as cause of death, we found sufficient remains to examine 21. All of these presented evidence consistent with predation (i.e., subcutaneous hemorrhaging or aspirated blood in the trachea) and none appeared emaciated, suggesting that all were healthy prior to death. Based on field methods, we were able to assign predator species to 33 of 45 neonates suspected of being depredated. Mitochondrial DNA testing successfully identified predator species from 34 neonates $(76 \% ; 12$ in 2013, 7 in 2014, 15 in 2015). Among this subsample, 15 were black bear, 8 were bobcat, 6 were coyote, 2 contained both black bear and bobcat DNA, 1 contained both coyote and black bear DNA, 1 contained both coyote and bobcat DNA, and 1 contained bobcat and mixed DNA (more than one species on a single swab). We assigned cause of death to both of the neonates with bobcat and black bear DNA as bobcat. Because black bears generally leave only bone fragments after

Table 2. Annual and overall survival rates based on a Kaplan-Meier model among radio-collared white-tailed deer neonates at Tensas River National Wildlife Refuge, Louisiana, USA, 2013-2015.

\begin{tabular}{lcccc}
\hline Yr & $\boldsymbol{n}$ & Survival rate & SE & $\mathbf{9 5 \%}$ CI \\
\hline 2013 & 28 & 0.357 & 0.091 & $0.217-0.587$ \\
2014 & 17 & 0.235 & 0.103 & $0.100-0.554$ \\
2015 & 25 & 0.200 & 0.080 & $0.091-0.438$ \\
Overall & 70 & 0.271 & 0.053 & $0.185-0.398$ \\
\hline
\end{tabular}

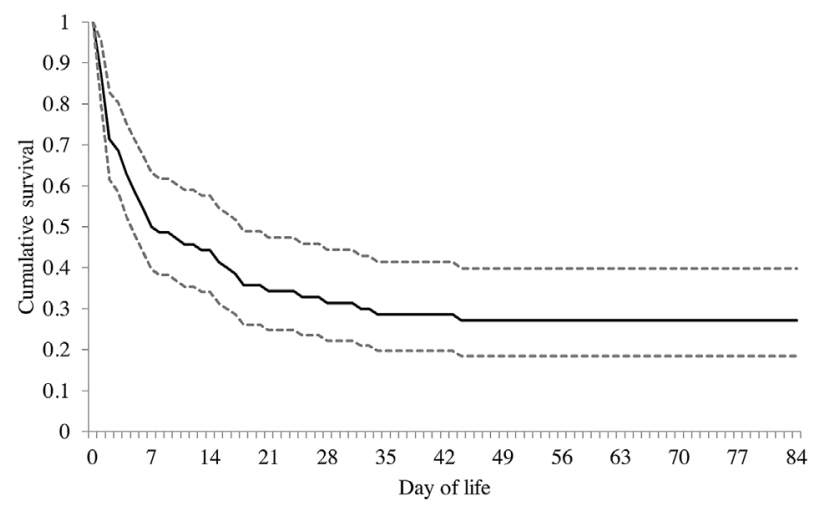

Figure 2. Survivorship curve based on Kaplan-Meier model for radiocollared white-tailed deer neonates from birth to 12 weeks old at Tensas River National Wildlife Refuge, Louisiana, USA, 2013-2015. Dashed lines represent $95 \%$ confidence interval.

feeding (Mathews and Porter 1988, Bertrum and Vivion 2002), whereas bobcats seldom consume an entire carcass (O'Gara 1978), we assumed it was more likely that the neonate was scavenged by a black bear after a bobcat killed it than vice versa. We assigned cause of death to the neonate with black bear and coyote DNA as coyote because most of the carcass was buried in the mineral soil and we saw a black bear at the carcass when we arrived to assess cause of death. For the neonate with coyote and bobcat DNA and the neonate with bobcat and mixed DNA, we assigned the cause of death as unknown predator because we did not have sufficient field evidence to determine predator versus scavenger species. In all other cases, DNA identifications confirmed our field assignments. Therefore, we relied on field evidence to assign predator species without DNA confirmation.

Black bear predation was the most frequent cause of mortality, accounting for $33 \%$ of all mortalities $(n=17$; Table 5). Coyotes accounted for $18 \%$ of all deaths $(n=9)$, and bobcats caused $22 \%$ of mortalities $(n=11$; Table 5$)$. We were unable to assign $16 \%$ of depredated neonates $(n=8)$ to a specific predator (Table 5). The most vulnerable time period for neonates was their first week of life, with 71\% (36 of 51) of all mortality occurring during this period (Fig. 3). Ninety-four percent $(n=48)$ of mortalities occurred within the first month, and the remaining 3 mortalities occurred thereafter (Fig. 3). Most mortalities caused by black bears and coyotes occurred in the first week of life ( $82 \%$ and $67 \%$, respectively), whereas most mortalities caused by bobcat occurred in the third week of life (45\%; Fig. 3).

\section{DISCUSSION}

Our study provided the first evaluation of white-tailed deer neonate survival and cause-specific mortality in areas of the southeastern United States with 3 sympatric predators (coyote, black bear, and bobcat) that depredate neonates. We observed a neonate survival rate of $27 \%$, which was low relative to other published works in the midwestern and northeastern United States (70\%, Nelson and Woolf 1987; 84\%, Brinkman et al. 2004; 91\%, Pusateri Burroughs et al. 
Table 3. Model selection results from Cox proportional hazard model analysis of survival of white-tailed deer neonates on Tensas River National Wildlife Refuge, Louisiana, USA, 2013-2015. We ranked candidate models using change in Akaike's Information Criterion for small sample size $\left(\Delta\right.$ AIC $\left._{c}\right)$ and Akaike weights $\left(w_{i}\right)$. We present only the top 5 candidate models here.

\begin{tabular}{|c|c|c|c|c|c|}
\hline Model $^{\mathbf{a}}$ & $K^{\mathbf{b}}$ & $\mathrm{AIC}_{c}$ & $\Delta \mathrm{AIC}_{c}$ & $w_{i}$ & Deviance \\
\hline $\mathrm{Sex}+$ mass + crop $+\operatorname{ref} 10+\operatorname{ref} 30$ & 5 & 365.80 & 0.00 & 0.46 & 354.86 \\
\hline Mass + crop + ref $10+\operatorname{ref} 30$ & 4 & 367.18 & 1.38 & 0.23 & 358.56 \\
\hline Sex + mass + crop + ref $10+$ ref $30+$ edge & 6 & 368.02 & 2.22 & 0.15 & 354.68 \\
\hline Sex + mass + edge & 7 & 370.03 & 4.23 & 0.06 & 363.66 \\
\hline Sex + mass + crop + ref $10+$ ref $20+$ ref $30+$ edge & 3 & 370.48 & 4.69 & 0.04 & 354.68 \\
\hline
\end{tabular}

${ }^{a}$ Crop, distance to cropland; ref10, distance to young reforestation (planted 2000-2009); ref20, distance to mid-age reforestation (planted 1990-1999); ref30, distance to old reforestation (planted 1980-1989); edge, distance to edge.

b No. parameters.

2006; 61\%, Rohm et al. 2007) and relative to survival rates in other 3-predator systems, 56\% in New Brunswick (Ballard et al. 1999) and 50\% in Pennsylvania (Vreeland et al. 2004), and in 4-predator systems, $50 \%$ in Michigan (Duquette et al. 2014) and 47\% in Minnesota (Carstensen et al. 2009). However, our findings were comparable to recently published studies conducted in 2-predator systems (coyote and bobcat) in the southeastern United States. For instance, survival rates were $17 \%$ and $22 \%$ in South Carolina (Epstein et al. 1985, Kilgo et al. 2012), 14\% in North Carolina (Chitwood et al. 2015b), 29\% in Georgia (Nelson et al. 2015), and 33\% and 22\% in Alabama (Saalfeld and Ditchkoff 2007, Jackson and Ditchkoff 2013). The greatest source of mortality in our study was predation (88\%) by black bear, coyote, and bobcat. Despite the uncertainty associated with assigning causes of death, our use of DNA to assign predator species helped to decrease uncertainty; DNA assignments paralleled our field assignments in all cases. Regardless, our estimates of predation attributed to black bears, coyotes, and bobcats may be conservative because of the number of mortalities where predation was evident but predator assignment was not possible. Given that neonate survival in the 3-predator system at Tensas was greater than in several of the 2-predator systems in the studies cited above, we suggest that an upper limit to predation rate may exist for white-tailed deer neonates. Research indicates that the presence of multiple predators using the same prey item can have a risk-reducing effect where prey consumption rates are lower than the expected rate based on the independent effects

Table 4. Coefficients, standard errors, and $95 \%$ confidence intervals for covariates in top Cox proportional hazard model predicting risk to whitetailed deer neonate survival on Tensas River National Wildlife Refuge, Louisiana, USA, 2013-2015.

\begin{tabular}{lccccc}
\hline & & & & \multicolumn{2}{c}{ HR $^{\mathbf{b}}$ 95\% CI } \\
\cline { 5 - 6 } Covariate $^{\mathbf{a}}$ & Coefficient & SE & HR $^{\mathbf{b}}$ & Lower & Upper \\
\hline Sex & 0.593 & 0.312 & 1.810 & 0.983 & 3.333 \\
Mass & -1.645 & 0.408 & 0.193 & 0.087 & 0.429 \\
Ref10 & -0.080 & 0.029 & 0.923 & 0.872 & 0.977 \\
Ref30 & 0.109 & 0.035 & 1.115 & 1.041 & 1.193 \\
Crop & -0.086 & 0.024 & 0.917 & 0.876 & 0.961 \\
\hline
\end{tabular}

${ }^{a}$ Mass, mass at birth (kg); ref10, distance to young reforestation (planted 2000-2009; $100 \mathrm{~m}$ ); ref30, distance to old reforestation (planted 1980$1989 ; 100 \mathrm{~m})$; crop, distance to cropland $(100 \mathrm{~m})$.

b Hazard ratio. of each predator (Sih et al. 1998). Therefore, the presence of additional predators in a system may not reduce fawn survival rates.

Historically, studies assessing neonate survival have captured neonates using grid searches (Ballard et al. 1999, Pusateri Burroughs et al. 2006), spotlighting (Carroll and Brown 1977), observing adult female behavior (Nelson and Woolf 1987, Vreeland et al. 2004), and monitoring of radiocollared females (Kunkel and Mech 1999). These methods rarely allow researchers to find neonates $<24$ hours old, and most captured neonates are several days up to 2 weeks old. We observed (as have others) most neonate mortality occurring during the first week of life. Hence, older neonates captured or sampled in earlier studies may have already survived a potentially critical period and likely biased estimates of neonate survival high (Gilbert et al. 2014). More recent studies have used VITs to locate neonates (Saalfield and Ditchkoff 2007, Carstensen et al. 2009, Kilgo et al. 2012), allowing a less biased assessment of neonate survival (Gilbert et al. 2014). Despite the use of VITs, we observed 3 instances where we arrived at the birth site within 2 hours of the expulsion of the VIT and did not find neonates. In each instance, the female was 100-200 m away from the VIT, and the VIT was lying at an obvious birth site still damp with placental fluid. At all 3 sites, we conducted visual and thermal searches multiple times without finding neonates, but in one instance observed a black bear within $75 \mathrm{~m}$ of the birth site during the initial search. Although it is possible that the neonates had moved away prior to our

Table 5. Causes of mortality among radio-collared white-tailed deer neonates at Tensas River National Wildlife Refuge, Louisiana, USA, 2013-2015.

\begin{tabular}{|c|c|c|c|c|c|c|c|c|}
\hline \multirow[b]{2}{*}{ Cause of mortality } & \multicolumn{2}{|c|}{2013} & \multicolumn{2}{|c|}{2014} & \multicolumn{2}{|c|}{2015} & \multicolumn{2}{|c|}{ Total } \\
\hline & $n$ & $\%$ & $n$ & $\%$ & $n$ & $\%$ & $n$ & $\%$ \\
\hline \multicolumn{9}{|l|}{ Predation } \\
\hline Black bear & 6 & 33.3 & 6 & 46.2 & 5 & 25.0 & 17 & 33.3 \\
\hline Bobcat & 5 & 27.8 & 1 & 7.7 & 5 & 25.0 & 11 & 21.6 \\
\hline Coyote & 4 & 22.2 & 1 & 7.7 & 4 & 20.0 & 9 & 17.6 \\
\hline Unknown & 2 & 11.1 & 4 & 30.8 & 2 & 10.0 & 8 & 15.7 \\
\hline Other causes ${ }^{\mathrm{a}}$ & 0 & 0.0 & 1 & 7.7 & 0 & 0.0 & 1 & 2.0 \\
\hline Unknown & 1 & 5.6 & 0 & 0.0 & 0 & 0.0 & 1 & 2.0 \\
\hline Starvation & 0 & 0.0 & 0 & 0.0 & 4 & 20.0 & 4 & 7.8 \\
\hline
\end{tabular}

${ }^{a}$ Dehydration and heart failure due to multiple birth defects. 


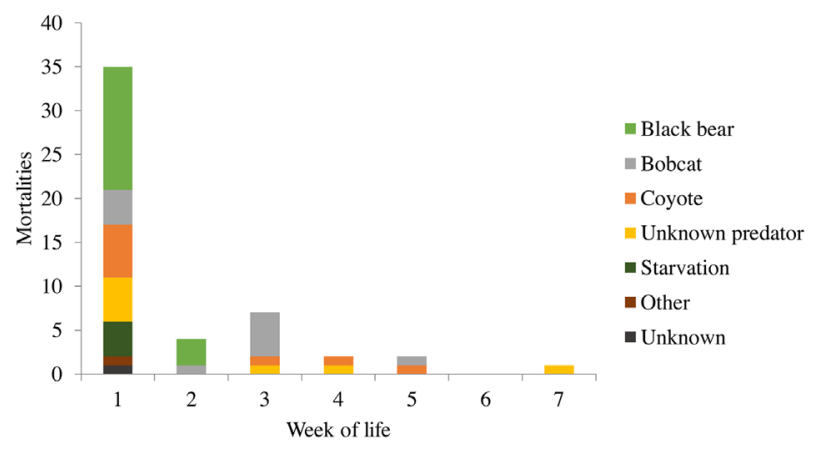

Figure 3. Number of mortalities by cause and week of life among radiocollared white-tailed deer neonates at Tensas River National Wildlife Refuge, Louisiana, USA, 2013-2015.

arrival, they would have had to have done so $\leq 2$ hours of birth, unlikely given that for all other birth events we monitored $\leq 3$ hours of parturition $(n=17)$, neonates were still bedded at the birth site. Thus, we suggest it is more plausible that these neonates were depredated prior to us being able to capture them, despite our rigorous monitoring protocol.

Predation by black bear was the greatest source of mortality (33\%), consistent with studies conducted in Pennsylvania, Minnesota, and New York where predation by black bears accounted for 25-60\% of mortalities attributable to predation (Mathews and Porter 1988, Kunkel and Mech 1994, Vreeland et al. 2004, Carstensen et al. 2009). Likewise, in a review of elk (Cervus canadensis) and moose (Alces alces) calf mortality, researchers reported that black bears were consistently the most important source of mortality (Zager and Beecham 2006). The density of black bears on Tensas is the highest in the state of Louisiana (Troxler 2013) and is $\geq 0.66$ bears $/ \mathrm{km}^{2}$ (Hooker 2010). The relevance of black bear predation on neonate ungulates tends to be positively correlated with bear density, although the relationship is not entirely proportional (Zagar and Beecham 2006). For instance, Ballard (1992) reported that mortality rates of elk and moose calves caused by black bears ranged from $2-50 \%$ when black bear densities were $0.02-0.57$ bears $/ \mathrm{km}^{2}$, and black bears were a substantial cause of moose calf mortality when they occurred at densities of $>0.2$ bears $/ \mathrm{km}^{2}$.

Bobcat predation was the second greatest source of neonate mortality. Where bobcats are sympatric with coyotes, bobcat predation may be low, accounting for $<10 \%$ of mortalities (Vreeland et al. 2004, Kilgo et al. 2012, Nelson et al. 2015), and coyotes tend to have a greater occurrence of deer in their diets than do bobcats (Litvaitis and Harrison 1989, VanGilder et al. 2009). However, deer can be an important prey item for bobcats in some areas (Chamberlain and Leopold 1999, Roberts 2007) and neonates provide more energy than small mammals (VanDomelen 1992). Hence, it is advantageous energetically for bobcats to consume neonates even in the presence of alternate prey. Bobcats are considered opportunistic predators (McCord and Cardoza 1982) and may exhibit a functional response to prey abundance, with increased use of preferred prey items when abundance is high (Baker et al. 2001). Bobcat predation on neonates is often low in areas of low deer densities (Kilgo et al. 2012, Chitwood et al. 2015b, Nelson et al. 2015), but deer abundance on Tensas was relatively high, indicating that bobcats on Tensas are likely taking advantage of the abundance of neonates available during the birthing period.

Coyote predation on Tensas was low (18\%) compared to other neonate survival studies performed in the southeastern United States, where $42-80 \%$ of mortalities were attributed to coyotes (Saalfeld and Ditchkoff 2007, Kilgo et al 2012, Jackson and Ditchkoff 2013, Chitwood et al. 2015b, Nelson et al. 2015). The relatively low prevalence of coyote predation on Tensas may be a result of prey partitioning with bears and bobcats. Resource partitioning permits sympatric predators to coexist (Ricklefs 2007). Predators often partition prey (Schoener 1974, Carvalho and Gomes 2004, Thornton et al. 2004, Andheria et al. 2007), but diets can converge when a resource is abundant (Schoener 1982). Neonate availability is high during the pulse of neonate births but declines as mortality events occur. At lesser neonate densities, energetic costs of preying upon neonates should increase as predators expend more time searching (Krebs 1978), and predators should benefit by using other food resources (Stephens and Krebs 1986). Bears consumed neonates primarily during the neonates' first week of life but coyotes depredated neonates to 5 weeks of life. Hence, coyote predation rates may have been higher if bears had not depredated neonates first. Coyotes are generalist carnivores with spatially and temporally variable diets (Wooding 1984, Andelt et al. 1987, Blanton and Hill 1989, Schrecengost et al. 2008). Many factors, including coyote density, deer density, abundance of alternative food sources, and vegetative hiding cover, could potentially influence the amount of coyote predation on neonates (Patterson and Messier 2000). Tensas contained a variety of vegetation communities that provide an abundance of alternative food resources, including soft mast, lagomorphs, and small mammals. As neonates age and become more mobile, coyotes simply shift to more easily obtainable food items (Petroelje et al. 2014). Studies manipulating predator densities are needed to adequately understand relative predation levels among multiple predators.

Proximity to certain land cover types may influence the ability of predators to detect and capture prey (Gese et al. 1996, Dijak and Thompson 2000). Predation risk at Tensas increased with proximity to cropland and young reforestation. Similarly, research in South Dakota reported increased probability of capture by a predator was associated with decreased distance to agriculture because neonates were more likely to be captured when fleeing to agricultural fields (Grovenburg et al. 2012). However, Grovenburg et al. (2012) also reported reduced predation risk when neonates were closer to thick vegetative cover (wetlands and grasslands), whereas at Tensas risk increased closer to cover (young reforestation). Grovenburg et al. (2012) hypothesized that neonates were more likely to escape predation when fleeing to thick cover. In contrast, White et al. (2010) observed an increased risk of predation in elk calves in scrub-fields because 
the thick vegetation served as a structural impediment to escape. We speculate that the dense herbaceous vegetation and woody thickets in the understory of young reforestation stands on TRNWR could impede escape of older neonates from predators.

Habitat use patterns of predators can influence their distribution and densities (King et al. 1998, Dijak and Thompson 2000) and may thereby explain patterns we observed in predation risk. For example, although bobcat habitat selection varies seasonally and spatially (Fuller et al. 1985, Anderson 1987, Chamberlain et al. 2003), bobcats often prefer dense early-successional or shrubby habitats (Hall and Newsom 1976, Rolley and Warde 1985, Litvaitis et al. 1986) such as those in young reforestation sites at TRNWR. Because bobcat hunting behavior typically consists of stalking and attacking prey from the concealment of cover (Kruuk 1986), bobcats may select early successional habitats because they contain more vegetative cover (Kolowski and Woolf 2002) or have greater prey abundance (Hall and Newsom 1976, Rucker et al. 1989, Knick 1990, Chamberlain et al. 2003). Likewise, research on female black bears in the Tensas River Basin showed that they selected swamps, water, agricultural areas, regenerating forest, and corridors in summer (i.e., during the birthing season; Benson and Chamberlain 2007). Regenerating forests were most likely selected because they contain abundant soft mast resources, including blackberry, which represents an important food item for bears on TRNWR (Weaver 1999, Benson and Chamberlain 2006). Female black bears on TRNWR also selected agricultural areas during summer, presumably to exploit available crops (Benson and Chamberlain 2007). Food habits of bears in the Tensas River Basin during summer and fall are dominated by agricultural crops, particularly corn (Anderson 1997, Weaver 1999, Benson and Chamberlain 2006). Bastille-Rousseau et al. (2011) concluded that when foraging, most black bears did not select for sites that had a high probability of occurrence of neonatal ungulates, but rather, selected for sites with high vegetative biomass. Thus, the rate of predation on neonates by black bears we observed may simply result from a high bear and deer density, in that as bears move into croplands and young reforestation areas to forage on other abundant food resources, the probability of a bear opportunistically encountering and consuming a neonate increases.

\section{MANAGEMENT IMPLICATIONS}

Current population projections indicate that predation on neonates is not causing population decline on Tensas (Shuman 2016), but continued predator population growth in combination with an unchanged harvesting regime may decrease neonate survival below sustainable levels. Our data demonstrate that black bear predation on neonates can be substantial. However, the recent delisting of the previously threatened Louisiana black bear has given Louisiana Department of Wildlife and Fisheries authority over management and harvest regulations, which may result in reduced bear population densities and, in turn, increased neonate survival. Therefore, managers will need to weigh impacts of black bear harvest on deer populations, bear populations, and public perception when evaluating harvest regulations.

\section{ACKNOWLEDGMENTS}

We thank M. T. Biggerstaff, Z. A. Haakoson, J. E. Graham, C. A. Kupar, K. A. McLean, C. D. Stelly, J. J. Thompson, and N. A. Yeldell for their assistance with field work. We thank D. A. Osborn for providing logistical support and M. A. Vukovich for aiding in statistical analysis. We thank Tensas River National Wildlife Refuge for in-kind support. Funding was provided by the Louisiana Department of Wildlife and Fisheries, the Central Louisiana and Northeast Louisiana chapters of the Quality Deer Management Association, and the Warnell School of Forestry and Natural Resources at the University of Georgia.

\section{LITERATURE CITED}

Andelt, W. F., J. G. Kie, F. F. Knowlton, and K. Cardwell. 1987. Variation in coyote diets associated with season and successional changes in vegetation. Journal of Wildlife Management 51:273-277.

Anderson, E. M. 1987. A critical review and annotated bibliography of literature on the bobcat. Colorado Division of Wildlife Special Report No. 62, Denver, USA.

Anderson, D. R. 1997. Corridor use, feeding ecology, and habitat relationships of black bears in a fragmented landscape in Louisiana. Thesis, University of Tennessee, Knoxville, USA.

Andheria, A. P., K. U. Karanth, and N. S. Kumar. 2007. Diet and prey profiles of three sympatric large carnivores in Bandipur Tiger Reserve, India. Journal of Zoology 273:169-175.

Baker, L. A., R. J. Warren, D. R. Diefenbach, W. E. James, and M. J. Conroy. 2001. Prey selection by reintroduced bobcats (Lynx rufus) on Cumberland Island, Georgia. American Midland Naturalist 145:80-93.

Ballard, W. B. 1992. Bear predation on moose: a review of recent North American studies and their management implications. Alces (Supplement) $1: 1-15$.

Ballard, W. B., A. W. Franzmann, and K. P. Taylor. 1979. Comparison of techniques utilized to determine moose calf mortality in Alaska. Proceedings of the North American Moose Conference and Workshop 15:363-387.

Ballard, W. B., H. A. Whitlaw, S. J. Young, R. A. Jenkins, and G. J. Forbes. 1999. Predation and survival of white-tailed deer fawns in northcentral New Brunswick. Journal of Wildlife Management 63:574-579.

Bastille-Rousseau, G., D. Fortin, C. Dussault, R. Courtois, and J. P. Ouellet. 2011. Foraging strategies by omnivores: are black bears actively searching for ungulate neonates or are they simply opportunistic predators? Ecography 34:588-596.

Benson, J. F., and M. J. Chamberlain. 2006. Food habits of Louisiana black bears (Ursus americanus luteolus) in two subpopulations of the Tensas River Basin. American Midland Naturalist 156:118-127.

Benson, J. F., and M. J. Chamberlain. 2007. Space use and habitat selection by female Louisiana black bears in the Tensas River Basin of Louisiana. Journal of Wildlife Management 71:117-126.

Bertrum, M. R., and M. T. Vivion. 2002. Moose mortality in eastern interior Alaska. Journal of Wildlife Management 66:747-756.

Bishop, C. J., G. C. White, D. J. Freddy, B. E. Watkins, and T. R. Stephenson. 2009. Effect of enhanced nutrition on mule deer population rate of change. Wildlife Monographs 172:1-28.

Bishop, C. J., G. C. White, and P. M. Lukacs. 2008. Evaluating dependence among mule deer siblings in fetal and neonatal survival analysis. Journal of Wildlife Management 72:1085-1093.

Blanton, K., and E. Hill. 1989. Coyote use of white-tailed deer fawns in relation to deer density. Proceedings of the Southeastern Association of Fish and Wildlife Agencies 43:470-478.

Boerson, M. R., J. D. Clark, and T. L. King. 2003. Estimating black bear population density and genetic diversity at Tensas River, Louisiana using microsatellite DNA markers. Wildlife Society Bulletin 31:197-207. 
Bowden, D. C., G. C. White, and R. M. Bartmann. 2000. Optimal allocation of sampling effort for monitoring a harvested mule deer population. Journal of Wildlife Management 64:1013-1024.

Brinkman, T. J., J. A. Jenks, C. S. DePerno, B. S. Haroldson, and R. G. Osborn. 2004. Survival of white-tailed deer in an intensively farmed region of Minnesota. Wildlife Society Bulletin 32:726-731.

Burnham, K. P., and D. R. Anderson. 2002. Model selection and multimodel inference: a practical information-theoretic approach. Second edition. Springer-Verlag, New York, New York, USA.

Carroll, B. K., and D. L. Brown. 1977. Factors affecting neonatal fawn survival in southern-central Texas. Journal of Wildlife Management 41: 63-69.

Carstensen, M., G. D. DelGiudice, and B. A. Sampson. 2003. Using doe behavior and vaginal-implant transmitters to capture neonate white-tailed deer in north-central Minnesota. Wildlife Society Bulletin 31:634-641.

Carstensen, M., G. D. DelGiudice, B. A. Sampson, and D. W. Kuehn. 2009. Survival, birth characteristics, and cause-specific mortality of whitetailed deer neonates. Journal of Wildlife Management 73:175-183.

Carstensen Powell, M., G. D. DelGiudice, and B. A. Sampson. 2005. Low risk of marking-induced abandonment in free-ranging white-tailed deer neonates. Wildlife Society Bulletin 33:643-655.

Carvalho, J. C., and P. Gomes. 2004. Feeding resource partitioning among four sympatric carnivores in the Peneda-Gerês National Park (Portugal). Journal of Zoology 263:275-283.

Chamberlain, M. J., L. M. Conner, and B. D. Leopold. 2003. Space use, movements, and habitat selection of adult bobcats (Lynx rufus) in central Mississippi. American Midland Naturalist 149:395-405.

Chamberlain, M. J., and B. D. Leopold. 1999. Dietary patterns of sympatric bobcats and coyotes in central Mississippi. Proceedings of the Southeastern Association of Fish and Wildlife Agencies 53:204-219.

Cherry, M. J., M. A. Nelson, R. J. Warren, and L. M. Conner. 2013. Photo sensors increase likelihood of detection of expelled vaginal implant transmitters. Wildlife Society Bulletin 37:846-850.

Chitwood, M. C., M. A. Lashley, J. C. Kilgo, C. E. Moorman, and C. E. Deperno. 2015a. White-tailed deer population dynamics and adult female survival in the presence of a novel predator. Journal of Wildlife Management 79:211-219.

Chitwood, M. C., M. A. Lashley, J. C. Kilgo, K. H. Pollock, C. E. Moorman, and C. S. DePerno. 2015b. Do biological and bedsite characteristics influence survival of neonatal white-tailed deer? PLoS ONE 10(3):e0119070.

Clark, K. L., and R. J. Robertson. 1979. Spatial and temporal multi-species nesting aggregations in birds as anti-parasite and anti-predator defenses. Behavioral Ecology and Sociobiology 5:359-371.

Cook, J. G., B. K. Johnson, R. C. Cook, R. A. Riggs, T. Delcurto, L. D. Bryant, and L. L. Irwin. 2004. Effects of summer-autumn nutrition and parturition date on reproduction and survival of elk. Wildlife Monographs 155:1-61.

Cook, R. S., M. White, D. O. Trainer, and W. C. Glazener. 1971. Mortality of young white-tailed deer fawns in south Texas. Journal of Wildlife Management 35:47-56.

Dijak, W. D., and F. R. Thompson. 2000. Landscape and edge effects on the distribution of mammalian predators in Missouri. Journal of Wildlife Management 64:209-216.

Duquette, J. F., J. L. Belant, N. J. Svoboda, D. E. Beyer Jr., and P. E. Lederle. 2014. Maternal nutrition, resource use and multi-predator risk on neonatal white-tailed deer survival. PLoS ONE 9(6):e100841.

Epstein, M. B., G. A. Feldhamer, and R. L. Joyner. 1983. Predation on white-tailed deer fawns by bobcat, foxes, and alligators: predator assessment. Proceedings of the Southeastern Association of Fish and Wildlife Agencies 37:161-172.

Epstein, M. B., G. A. Feldhamer, R. L. Joyner, R. J. Hamilton, and W. G. Moore. 1985. Home range and mortality of white-tailed deer fawns in coastal South Carolina. Proceedings of the Southeastern Association of Fish and Wildlife Agencies 39:373-379.

Fritts, A. L., and T. N. Pearsons. 2008. Can non-native smallmouth bass, Micropterus dolomieu, be swamped by hatchery fish releases to increase juvenile Chinook salmon, Oncorhynchus tshawytscha, survival? Environmental Biology of Fishes 83:499-508.

Fuller, T. K., W. E. Berg, and D. W. Kuehn. 1985. Bobcat home range size and daytime cover type use in northcentral Minnesota. Journal of Mammology. 66:568-571.
Garner, G. W., J. A. Morrison, and J. C. Lewis. 1976. Mortality of white-tailed deer fawns in the Wichita Mountains, Oklahoma. Proceedings of the Southeastern Association of Fish and Wildlife Agencies 30:493-506.

Garner, G. W., J. Powell, and J. A. Morrison. 1979. Vegetative composition surrounding daytime bed sites of white-tailed deer in southwestern Oklahoma. Proceedings of the Southeastern Association of Fish and Wildlife Agencies 33:259-266.

Gese, E. M., R. L. Ruff, and R. L. Crabtree. 1996. Intrinsic and extrinsic factors influencing coyote predation of small mammals in Yellowstone National Park. Canadian Journal of Zoology 74:784-797.

Gilbert, S. L., M. S. Lindberg, K. J. Hundertmark, and D. K. Person. 2014. Dead before detection: addressing the effects of left truncation on survival estimation and ecological inference for neonates. Methods of Ecology and Evolution 5:992-1001.

Grovenburg, T. W., R. W. Klaver, and J. A. Jenks. 2012. Survival of whitetailed deer fawns in the grasslands of the northern great plains. Journal of Wildlife Management 76:944-956.

Hall, H. T., and J. D. Newsom. 1976. Summer home ranges and movement of bobcats in bottomland hardwoods of southern Louisiana. Proceedings of the Southeastern Association of Fish and Wildlife Agencies 30: 422-436.

Hooker, M. J. 2010. Estimating population parameters of the Louisiana black bear in the Tensas River Basin, Louisiana, using robust design capture-mark-recapture. Thesis, University of Tennessee, Knoxville, USA.

Howze, M. B., L. M. Conner, R. J. Warren, and K. V. Miller. 2009. Predator removal and white-tailed deer recruitment in southwestern Georgia. Proceedings of the Southeastern Association of Fish and Wildlife Agencies 63:17-20.

Huegel, C. N., R. B. Dahlgren, and H. L. Gladfelter. 1985. Mortality of white-tailed deer fawns in south-central Iowa. Journal of Wildlife Management 49:377-380.

Jackson, A. M., and S. S. Ditchkoff. 2013. Survival estimates of white-tailed deer fawns at Fort Rucker, Alabama. American Midland Naturalist 170:184-190.

Jackson, R. M., M. White, and F. F. Knowlton. 1972. Activity patterns of young white-tailed deer fawns in south Texas. Ecology 53:262-270.

Johnson, W. E., and S. J. O'Brien. 1997. Phylogenetic reconstruction of the Felidae using rRNA and NADH-5 mitochondrial genes. Journal of Molecular Evolution 44:S98-S116.

Kilgo, J. C., H. S. Ray, C. Ruth, and K. V. Miller. 2010. Can coyotes affect deer populations in southeastern North America? Journal of Wildlife Management 74:929-933.

Kilgo, J. C., H. S. Ray, M. Vukovich, M. J. Goode, and C. Ruth. 2012. Predation by coyotes on white-tailed deer neonates in South Carolina. Journal of Wildlife Management 76:1420-1430.

Kilgo, J. C., M. Vukovich, H. S. Ray, C. E. Shaw, and C. Ruth. 2014. Coyote removal, understory cover, and survival of white-tailed deer neonates. Journal of Wildlife Management 78:1261-1271.

King, D. I., C. R. Griffin, and R. M. DeGraaf. 1998. Nest predator distribution among clearcut forest, forest edge and forest interior in an extensively forested landscape. Forest Ecology and Management 104: 151-156.

Knick, S. T. 1990. Ecology of bobcats relative to exploitation and prey decline in southeastern Idaho. Wildlife Monographs 108:1-42.

Kolowski, J. M., and A. Woolf. 2002. Microhabitat use by bobcats in southern Illinois. Journal of Wildlife Management 66:822-832.

Krebs, J. R. 1978. Optimal foraging: decision rules for predators. Pages 23-63 in J. R. Krebs, and N. B. Davies, editors. Behavioral ecology: an evolutionary approach. Blackwell, Oxford, United Kingdom.

Kruuk, H. 1986. Interactions between felidae and their prey species: a review. Pages 353-374 in S. D. Miller, and D. Everett, editors. Cats of the world: biology, conservation, and management. National Wildlife Federation, Washington, D.C., USA.

Kunkel, K. E., and L. D. Mech. 1994. Wolf and bear predation on whitetailed deer fawns in northeastern Minnesota. Canadian Journal of Zoology 72:1557-1565.

Labisky, R. F., and M. C. Boulay. 1998. Behaviors of bobcats preying on white-tailed deer in the Everglades. American Midland Naturalist 139:275-281. 
Langenau, E. E. Jr., and J. M. Lerg. 1976. The effects of winter nutritional stress on maternal and neonatal behavior in penned white-tailed deer. Applied Animal Ethology 2:207-223.

Linnell, J. D. C., E. B. Nilsen, and R. Anderson. 1995. Who killed Bambi? The role of predation in the neonatal mortality of temperate ungulates. Wildlife Biology 1:209-244.

Litvaitis, J., and D. Harrison. 1989. Bobcat-coyote niche relationships during a period of coyote population increase. Canadian Journal of Zoology 67:1180-1188.

Litvaitis, J. A., J. A. Sherburne, and J. A. Bissonette. 1986. Bobcat habitat use and home range size in relation to prey density. Journal of Wildlife Management 50:110-117.

Lomas, L. A., and L. C. Bender. 2007. Survival and cause-specific mortality of neonatal mule deer fawns, north-central New Mexico. Journal of Wildlife Management 71:884-894.

Mathews, N. E., and W. F. Porter. 1988. Black bear predation of whitetailed deer neonates in the central Adirondacks. Canadian Journal of Zoology 66:1241-1242.

McCord, C. M., and J. E. Cardoza. 1982. Bobcat and lynx. Pages 728-766 in J. A. Chapman and G. A. Feldhamer, editors. Wild mammals of North America. Johns Hopkins University Press, Baltimore, Maryland, USA.

McCoy, M. W., A. C. Stier, and C. W. Osenberg. 2012. Emergent effects of multiple predators on prey survival: the importance of depletion and functional response. Ecology Letters 15:1449-1456.

Millspaugh, J. J., and J. M. Marzluff. 2001. Radio tracking and animal populations. Academic Press, Burlington, Massachusetts, USA.

National Oceanic and Atmospheric Administration. 2015. National Climatic Data Center. Weather observation station record for Tallulah, Louisiana. http://ncdc.noaa.gov/oa/climate/stationlocator.html. Accessed 25 Jan 2016.

Nelson, M. A. 2013. Habitat selection and survival of white-tailed deer fawns in a longleaf pine ecosystem. Thesis, University of Georgia, Athens, USA.

Nelson, M. A., M. J. Cherry, M. B. Howze, R. J. Warren, and L. M. Conner. 2015. Coyote and bobcat predation on white-tailed deer fawns in a longleaf pine ecosystem in southwestern Georgia. Journal of the Southeastern Association of Fish and Wildlife Agencies 2:208-213.

Nelson, T. A., and A. Woolf. 1987. Mortality of white-tailed deer fawns in southern Illinois. Journal of Wildlife Management 51:326-329.

Nowak, R. M. 1986. Status of the Louisiana black bear. Report for the Office of Endangered Species, U.S. Fish and Wildlife Service, Washington, D.C., USA.

O'Donoghue, M., and S. Boutin. 1995. Does reproductive synchrony affect juvenile survival rates of northern mammals? Oikos 74:115-121.

O'Gara, B. W. 1978. Differential characteristics of predator kills. Proceedings of the Biennial Pronghorn Antelope Workshop 8:380-393.

Ozoga, J. J., and R. K. Clute. 1988. Mortality rates of marked and unmarked fawns. Journal of Wildlife Management 52:549-551.

Ozoga, J. J., and L. J. Verme. 1982. Predation by black bears on newborn white-tailed deer. Journal of Mammalogy 63:695-696.

Patterson, B. R., and F. Messier. 2000. Factors influencing killing rates of white-tailed deer by coyotes in eastern Canada. Journal of Wildlife Management 64:721-732.

Petroelje, T. R., J. L. Belant, D. E. Beyer Jr., G. Wang, and B. D. Leopold. 2014. Population level response of coyotes to a pulsed resource event. Population Ecology 56:349-358.

Porath, W. R. 1980. Fawn mortality estimates in farmland deer range. Pages 55-63 in R. L. Hine and S. Nehls, editors. White-tailed deer population management in the North Central states. Proceedings of a Symposium, 41st Midwest Fish and Wildlife Conference, Urbana, Illinois, USA.

Pusateri Burroughs, J. P., H. Campa III, S. R. Winterstein, B. A. Rudolph, and W. E. Moritz. 2006. Cause-specific mortality and survival of whitetailed deer fawns in southwestern lower Michigan. Journal of Wildlife Management 70:743-751.

Ricklefs, R. E. 2007. History and diversity: explorations at the intersection of ecology and evolution. American Naturalist 170:S56-S70.

Roberts, S. B. 2007. Ecology of white-tailed deer and bobcats on Kiawah Island, South Carolina: implications for suburban habitat preservation. Dissertation, University of Georgia, Athens, USA

Robinson, K. F., D. R. Diefenbach, A. K. Fuller, J. E. Hurst, and C. S. Rosenberry. 2014. Can managers compensate for coyote predation of white-tailed deer? Journal of Wildlife Management 78:571-579.
Rohm, J. H., C. K. Nielson, and A. Woolf. 2007. Survival of white-tailed deer fawns in southern Illinois. Journal of Wildlife Management 71:851-860

Rolley, R. E., and W. D. Warde. 1985. Bobcat habitat use in southeastern Oklahoma. Journal of Wildlife Management 49:913-920.

Roseberry, J. L., and A. Woolf. 1991. A comparative evaluation of techniques for analyzing white-tailed deer harvest data. Wildlife Monographs 117:3-59.

Rucker, R. A., M. L. Kennedy, G. A. Heidt, and M. J. Harvey. 1989. Population density, movements, and habitat use of bobcats in Arkansas. Southwestern Naturalist 34:101-108.

Saalfeld, S. T., and S. S. Ditchkoff. 2007. Survival of neonatal white-tailed deer in an exurban population. Journal of Wildlife Management 71:940-944.

Schlegel, M. 1976. Factors affecting calf elk survival in northcentral Idaho. A progress report. Proceedings of the Annual Confernence of the Westerm Association of State Game and Fish Commissioners $56: 342-355$

Schoener, T. W. 1974. Resource partitioning in ecological communities. Science 185:27-39.

Schoener, T. W. 1982. The controversy over interspecific competition: despite spirited criticism, competition continues to occupy a major domain in ecological thought. American Scientist 70:586-595.

Schrecengost, J. D., J. C. Kilgo, D. Mallard, H. S. Ray, and K. V. Miller. 2008. Seasonal food habits of the coyote in the South Carolina coastal plain. Southeastern Naturalist 7:135-144.

Shuman, R. M. 2016. Population dynamics of white-tailed deer on Tensas River National Wildlife Refuge, Louisiana. Thesis, University of Georgia, Athens, USA.

Sih, A., G. Englund, and D. Wooster. 1998. Emergent impacts of multiple predators on prey. Trends in Ecology \& Evolution 13:350-355.

Steiger, S. 2013. Bigger mothers are better mothers: disentangling sizerelated prenatal and postnatal maternal effects. Proceedings of the Royal Society of London: Biological Sciences 280:20131225.

Stephens, D. W., and J. R. Krebs. 1986. Foraging theory. Princeton University Press, Princeton, New Jersey, USA.

Taber, R. D., and R. F. Dasmann. 1954. A sex difference in young Columbian black-tailed deer. Journal of Wildlife Management 18:309-315.

Thorne, E. T., R. D. Dean, and W. G. Hepworth. 1976. Nutrition during gestation in relation to successful reproduction in elk. Journal of Wildlife Management 40:330-335.

Thornton, D. H., M. E. Sunquist, and M. B. Main. 2004. Ecological separation within newly sympatric populations of coyotes and bobcats in south-central Florida. Journal of Mammology 85:973-982.

Troxler, J. C. 2013. Population demographics and genetic structure of black bears in coastal Louisiana. Thesis, University of Tennessee, Knoxville, USA.

U.S. Department of Agriculture. 1968. Natural Resources Conservation Service. Louisiana online soil survey manuscripts. http://soils.usda.gov/ survey/online_surveys/louisiana/index.html. Accessed 15 Nov 2015.

U.S. Geological Survey. 1995. Hydro-climatic data network: streamflow data set, 1874-1988. Region 08 Lower Mississippi. http://pubs.usgs.gov/ wri/wri934076/region08.html. Accessed 15 Nov 2015.

VanDomelen, E. D. 1992. Nutrition, prey assimilation, and bioenergetics of captive bobcats. Thesis, Mississippi State University, Mississippi State, USA.

VanGilder, C. L., G. R. Woods, and K. V. Miller. 2009. Effects of an intensive predator removal on white-tailed deer recruitment. Proceedings of the Southeastern Association of Fish and Wildlife Agencies 63:11-16.

Verme, L. J. 1969. Reproductive patterns of white-tailed deer related to nutritional plane. Journal of Wildlife Management 33:881-887.

Verme, L. J. 1989. Maternal investment in white-tailed deer. Journal of Wildlife Management 70:438-442.

Vreeland, J. K., D. R. Diefenbach, and B. D. Wallingford. 2004. Survival rates, mortality causes, and habitats of Pennsylvania white-tailed deer fawns. Wildlife Society Bulletin 32:542-553.

Wade, D. A., and J. E. Bowns. 1984. Procedures for evaluating predation on livestock and wildlife. Texas Agricultural Extension Service Publication Number B-1429. Texas Agricultural Experiment Station, Texas A\&M University, College Station, USA.

Weaver, K. M. 1999. The ecology and management of black bears in the Tensas River Basin of Louisiana. Dissertation, University of Tennessee, Knoxville, USA. 
White, M. 1973. Description of remains of deer fawns killed by coyotes. Journal of Mammalogy 54:291-293.

White, C. G., P. Zager, and M. W. Gratson. 2010. Influence of predator harvest, biological factors, and landscape on elk calf survival. Journal of Wildlife Management 74:355-369.

Whittaker, D. G., and F. G. Lindzey. 1999. Effect of coyote predation on early fawn survival in sympatric deer species. Wildlife Society Bulletin $27: 256-262$
Wooding, J. B. 1984. Coyote food habits and the spatial relationship of coyotes and foxes in Mississippi and Alabama. Thesis, Mississippi State University, Mississippi State, USA.

Zager, P., and J. Beecham. 2006. The role of American black bears and brown bears as predators on ungulates in North America. Ursus 17:95-108.

Associate Editor: Barbara Zimmermann. 